\author{
Bożena Wójtowicz \\ Uniwersytet Pedagogiczny \\ im. Komisji Edukacji Narodowej \\ w Krakowie
}

\title{
Strategia rozwoju a ocena jakości usług na przykładzie Zespołu Palacowego w Kurozwękach w świetle badań sondażowych
}

Uwarunkowania rynkowe, a także ryzyko występujące w działalności gospodarczej powinny skłaniać przedsiębiorstwa do reorientacji systemu zarządzania w kierunku podejścia strategicznego, poszukiwania i formułowania strategii umożliwiającej realizację określonych celów, a także dostosowania się do dynamicznych warunków działalności. Strategia to ogólnie sformułowana metoda osiągnięcia zamierzonych celów. Pojawia się ona w podejmowaniu przez firmę działań atakujących lub obronnych, mających na celu utrzymanie pozycji w danym sektorze, skuteczne radzenie sobie z siłami konkurencyjnymi i uzyskanie przez firmę wyższej stopy zysku. Przedsiębiorstwo musi bowiem myśleć o przyszłości, nie tylko o przetrwaniu, ale i o rozwoju. Musi więc swoją taktykę zastąpić strategią. Taktyka rozwiązuje sprawy doraźne, strategia zaś perspektywiczne. Taktyka służy do rozwiązywania problemów, strategia do tworzenia możliwości. Korzyści strategiczne zależą nie od podwyżek cenowych na własne produkty czy usługi, lecz od wysokiej jakości produkcji, wyprzedzenia innych w opracowaniu nowoczesnych wyrobów, udoskonalenia bądź wprowadzenia nowych technologii i organizacji.

Strategia w rozwoju i kreowaniu jakości usług należy do najważniejszych elementów zarządzania firmy. Strategia rozwoju jest podstawowym i niezbędnym dokumentem w procesie planowania i prognozowania kierunków rozwoju firmy. Wskazuje jego mocne strony i szanse, identyfikuje problemy i zagrożenia, określa cele oraz metody ich realizacji.

Pojęciem ,strategia” posługiwano się bardzo wcześnie, ale dopiero od lat trzydziestych XX wieku zaczęto je odnosić do takich dziedzin ludzkiej aktywności, jak polityka i gospodarka. Obecnie termin ten oznacza sposób działania będący systemem złożonym z działań szczegółowych (Stabryła 2002). W literaturze można znaleźć wiele różnych definicji dotyczących strategii, przy czym trudno jest zdefiniować jej pojęcie. Wiadomo natomiast, że jest ona jednym z najważniejszych elementów zarządzania. Od dobrej strategii zależy w dużej mierze sukces firmy.

$\mathrm{Na}$ użytek niniejszego artykułu przyjęto, iż strategia to długookresowa polityka działania firmy, która wytycza zasadnicze cele, optymalizuje alokację zasobów potrzebnych do osiągnięcia nadrzędnych jej celów, zachowując przy tym równowagę względem otoczenia (Penc 1997). Ponieważ strategia jest kategorią zmienną w czasie, nie można stworzyć jej wspólnej, jednoznacznie rozumianej definicji.

Jednym z najprężniej rozwijających się przedsiębiorstw, które stało się w ostatnich latach centrum turystycznym regionu świętokrzyskiego, jest Zespół Pałacowy w Kurozwękach. Po odzyskaniu w latach 90. ubiegłego wieku przez rodowitych właścicieli głównego zespołu pałacowego z XIV w., w którym mieszkały tak zacne rody, jak: Kurozwęccy, Lanckorońscy, 
Sołtykowie czy Popielowie, stał się znany w Polsce i na świecie. Każdego roku dzięki swoim walorom i atrakcjom turystycznym oraz dynamicznemu rozwojowi przyciąga coraz większą rzeszę turystów.

Celem niniejszego artykułu jest wskazanie podstawowych uwarunkowań i kierunków rozwoju przedsiębiorstwa turystycznego Zespołu Pałacowego w Kurozwękach w latach 20062008 oraz ocena jakości usług na podstawie badań sondażowych przeprowadzonych w latach 2008 i 2009 wśród osób przebywających na jego terenie. Przyjęto hipotezę, że rozwój przedsiębiorstwa turystycznego w Kurozwękach zależy od jego struktury organizacyjnej, strategii zatrudnienia oraz jakości usług.

\section{Struktura organizacyjna i strategia zatrudnienia}

Struktura organizacyjna to układ stanowisk i składających się z nich komórek organizacyjnych wewnątrz organizacji. Schemat struktury organizacyjnej różni się w zależności od typu struktury. Ze względu na układ więzi organizacyjnych wyodrębnia się cztery typy struktur: liniową, funkcjonalna, sztabową, macierzową.

Struktura liniowa opiera się na zasadzie jednoosobowego podporządkowania. Najważniejszą cechą tej więzi jest uprawnienie przełożonego do decydowania o tym, co podwładny ma robić w czasie pracy, i do określania zadań, które podwładny powinien wykonać. Struktura funkcjonalna charakteryzuje się występowaniem działów funkcjonalnych kierowanych przez specjalistów. Każdy pracownik podlega więcej niż jednemu kierownikowi. Występują przełożeni hierarchiczni (służbowi) oraz przełożeni funkcjonalni (wydający dyspozycje związane z wykonaniem konkretnych zadań). Struktury sztabowe (liniowo-funkcjonale) charakteryzują się tym, że więzi funkcjonalne są nałożone na więzi służbowe, co powoduje, iż doradcy funkcjonalni występują na różnych szczeblach zarządzania. Do ich zadań należy przygotowanie i opracowanie materiałów, które będą pomocne kierownikom w podjęciu ważnych decyzji. Struktura macierzowa polega na tym, że komórki organizacyjne, będące najczęściej doraźnymi zespołami roboczymi, ułożone są w macierz, która określona jest na zasadzie dwuwymiarowego grupowania. Zespoły te służą realizacji konkretnego projektu, np. wprowadzeniu nowego produktu na rynek (Szałkowski 2000). W Zespole Pałacowym w Kurozwękach nie ma jednolitego typu struktury, jednak jest on najbardziej zbliżony do struktury liniowej (ryc. 1).

Jedną z ważniejszych strategii w strukturze liniowego zarządzania jest strategia zatrudnienia, która powinna zawierać konkretne, praktyczne rozwiązania w ramach zakresów zadań. Powinno z niej wynikać, jak się w firmie rekrutuje, dokonuje ocen okresowych, szkoli pracowników itd. Musi być także wyraźny związek między tymi zadaniami (np. między oceną a rozwojem i motywowaniem). Opracowanie każdego z tych zadań wymaga współpracy i konsultacji osób spoza działu personalnego (Szałkowski (red.) 2000).

Strategia personalna precyzuje kierunki, cele i zasady gospodarowania zasobami ludzkimi w przedsiębiorstwie. Dobrze opracowana strategia personalna powinna zawierać plan dopasowania istniejącego potencjału pracowników firmy do realizacji celów, jakie firma ma realizować w przyszłości. Takie działania wymagają oceny potencjału ludzkiego.

Sposób zarządzania personelem w Zespole Pałacowym można podzielić na kilka etapów. Podczas planowania personelu analizowane są czynniki wewnętrzne oraz czynniki otoczenia organizacji. Dokonuje się przeglądu personelu i stanowisk pracy, aby ustalić, czy potrzebni są nowi pracownicy. Zwykle odbywa się to na początku roku.

Celem rekrutacji jest wyszukanie i przygotowanie kandydatów zgodnie z ustalonym planem personalnym. Zespół Pałacowy to mała firma otwarta na rynek lokalny, dlatego kandy- 
datami są generalnie osoby mieszkające w pobliżu bądź skierowane przez Staszowski Urząd Pracy. Zadaniem selekcji kandydatów jest wybór pretendentów na podstawie dokonanych ocen. Wybór pracowników następuje po pierwszej trzymiesięcznej umowie próbnej. Jeżeli są jakieś wątpliwości, przedłuża się umowę próbną na kolejne sześć miesięcy. Po tym okresie próbnym zostaje podpisana umowa na dwa lata, następna znowu na dwa lata i w końcu trzecia na czas nieokreślony. Dodatkowo w sezonie letnim zatrudniane są osoby na umowę zlecenie. Wprowadzenie nowych pracowników ma na celu rozpoczęcie i ułatwienie przystosowania do organizacji. Misją szkolenia i doskonalenia pracowników jest zwiększenie umiejętności pracowników oraz skuteczności organizacji. Co pewien okres pracownicy wysyłani są na kursy i szkolenia organizowane przez urzędy m.in. nauka języka angielskiego, szkolenie na kelnera-barmana i wiele innych kursów podnoszących kwalifikacje.

Ryc. 1. Schemat organizacji w Zespole Pałacowym w Kurozwękach

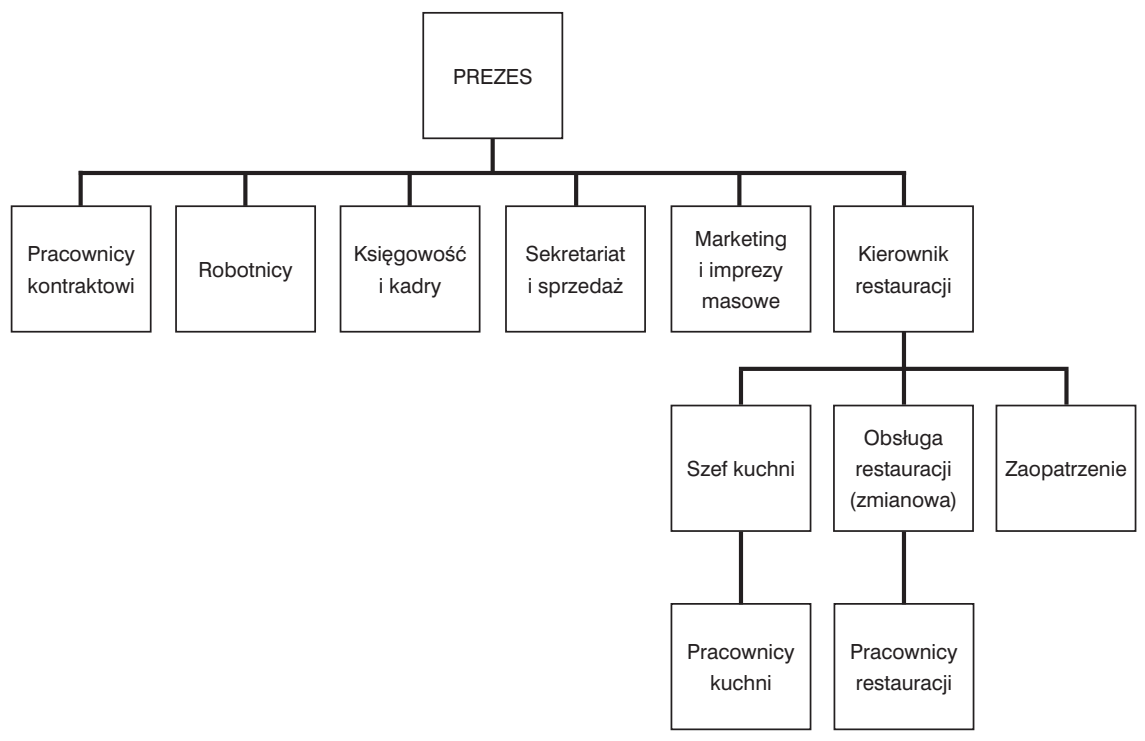

Źródło: opracowanie własne.

Celem oceny efektywności pracowników jest ustalanie osiąganych przez nich wyników, i porównanie ich do przyjętych norm i celów. Jeżeli pracownik jest efektywny, zostaje nagrodzony np. premią, podwyżka, pochwałą czy też awansem. W Zespole Pałacowym nie ma konkretnego systemu ocen. Pracownik otrzymuje wyróżnienie za własny wkład w rozwój firmy podczas codziennej pracy.

Przeniesienie pracownika następuje wówczas, gdy zatrudniony jest dobrym, sumiennym pracownikiem, ale bardziej może się wykazać na innym stanowisku. Istnieje nawet możliwość otwarcia specjalnie dla niego danego stanowiska.

Odejście pracownika następuje wskutek różnych sytuacji: rezygnacji z pracy, redukcji, przejścia na emeryturę, otwarcia własnej firmy bądź znalezienia lepszej pracy.

Jeżeli chodzi o liczbę osób zatrudnionych w Zespole Pałacowym, to z roku na rok się ona powiększa. Liczbę osób zatrudnionych na podstawie umowy o pracę w Zespole Pałacowym na przełomie trzech lat przedstawia ryc. 2 . 
Ryc. 2. Miesięczny poziom zatrudnienia na podstawie umowy o pracę w Zespole Pałacowym w Kurozwękach w latach 2006-2008

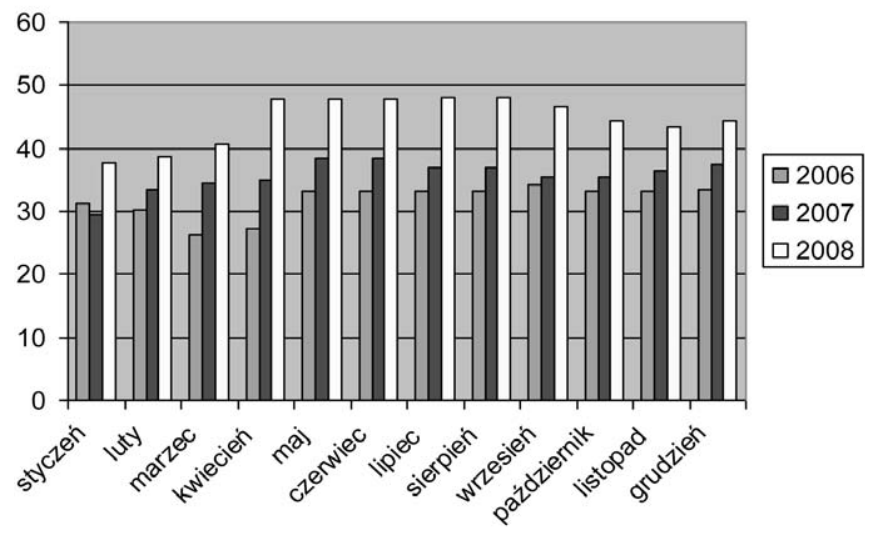

Źródło: opracowanie własne.

Ryc. 3. Dynamika zatrudnienia ogólnej liczby pracowników zatrudnionych na podstawie umowy o pracę w Zespole Pałacowym w Kurozwękach w latach 2006-2008

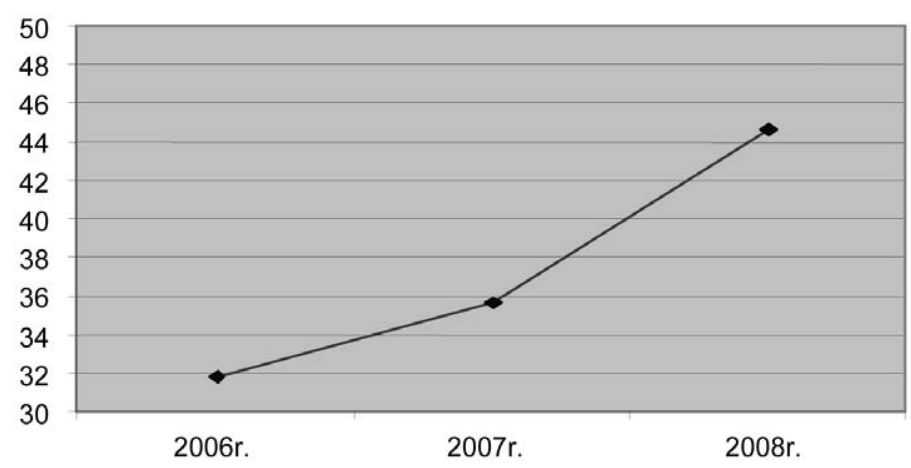

Źródło: opracowanie własne.

Na podstawie powyższych wykresów można zauważyć, iż w miarę rozwoju firmy wzrasta zapotrzebowanie na pracowników. Pierwszy rok analizowanego okresu charakteryzował się najmniejszą liczbą pracujących. W tym okresie nie odnotowano jeszcze dużych wahań zatrudnienia pomiędzy poszczególnymi miesiącami. Najmniej osób pracowało w miesiącach marcu i kwietniu, ponieważ nastąpiła wtedy likwidacja etatów, która miała związek ze złym stanem finansowym firmy. W kolejnych miesiącach nastąpił wzrost zatrudnienia wraz z otwarciem nowego sezonu. Do końca roku poziom zatrudnienia był stabilny i utrzymywał się w granicach 33 stanowisk. Średnio w 2006 roku pracowały 32 osoby zatrudnione na podstawie umowy o pracę. W trakcie kolejnych dwóch lat liczba pracowników Zespołu Pałacowego zwiększyła się. Początek roku jest dla firmy ciężkim okresem i przekłada się to na liczbę zatrudnianych osób. Tak było w roku 2007, kiedy zredukowano etaty do 29 stanowisk pracy. Od lutego 2007 roku nastąpił wzrost ich liczby. Najbardziej zauważalny był w miesiącach maju oraz czerwcu, kiedy na podstawie umowy o pracę zatrudniano aż 38 osób. Od lipca nastąpił nieznaczny spadek, który potrwał do grudnia. W roku 2007 na podstawie umowy o pracę pracowało średnio 
35 osób. W styczniu 2008 roku w Zespole Pałacowym było zatrudnionych 37 osób i z każdym miesiącem liczba ta wzrastała, a w lipcu oraz sierpniu osiągnięto największą liczbę stanowisk pracy w historii - 48. Uwarunkowane było to dwoma dużymi imprezami odbywającymi się na terenie Zespołu Pałacowego w Kurozwękach. W ostatnim badanym roku liczba zatrudnionych osób wzrosła średnio do 45. Największą wartość dynamiki odnotowano w działach administracji i obsługi. Wpłynął na to gwałtowny rozwój firmy. Natomiast jeżeli chodzi o sezonowość obiektu, jest ona najbardziej widoczna w dwóch poprzednich latach w miesiącach maj-sierpień. Największy wzrost liczby stanowisk pracy nastąpił w dziale obsługi.

Ryc. 4. Dynamika zatrudnienia pracowników w poszczególnych działach zatrudnionych na podstawie umowy o pracę w Zespole Pałacowym w Kurozwękach w latach 2006-2008

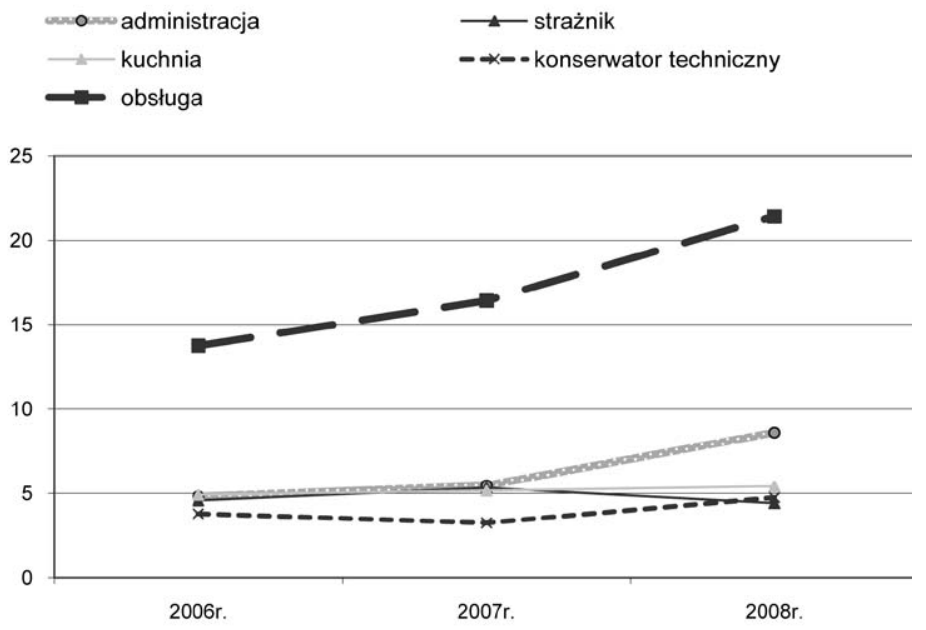

Źródło: opracowanie własne.

\section{Badania jakości usług w Zespole Pałacowym - analiza uzyskanych wyników badań}

Zespół Pałacowy w Kurozwękach zajmuje szóste miejsce w województwie świętokrzyskim pod względem liczby turystów. W celu sprawdzenia jakości usług wykonywanych na terenie obiektu pod koniec 2008 roku i wiosną 2009 roku została przeprowadzona ankieta wśród gości nocujących w obiekcie hotelarskim. Do Zespołu Pałacowego w Kurozwękach w roku 2008 przyjechało blisko 80 tysięcy turystów, z czego do badań losowo zostało wybranych 657 osób, które odpowiedziały na pytania zawarte w kwestionariuszu ankiety składającym się z metryczki oraz 9 pytań zamkniętych i 4 otwartych. Ankieta została przeprowadzona w celu sprawdzenia jakości usług wykonywanych w Zespole Pałacowym w Kurozwękach oraz podniesienia jakości świadczeń w tym obiekcie. Podobną ankietę przeprowadzono w maju 2005 roku i niektóre wyniki można było porównać do zmian, które zaszły w tym obiekcie w ciagu czterech lat.

Pierwsze pytanie dotyczyło danych osobowych ankietowanych, a mianowicie płci, wieku (ryc. 5), wykształcenia (ryc. 6) oraz miejsca zamieszkania (ryc. 7). Okazało się, że do Kurozwęk przyjeżdża więcej kobiet (58\%) niż mężczyzn (42\%) i przeważają osoby młode (31\%). Najmniej przyjeżdża do obiektu osób powyżej 56 roku życia (15\%), chociaż różnice pomiędzy innymi kategoriami wiekowymi wynoszą 1\%. Świadczy to o tym, że obiekt ten może być wykorzystywany przez osoby w różnym wieku (ryc. 5). 
Ryc. 5. Wiek ankietowanych

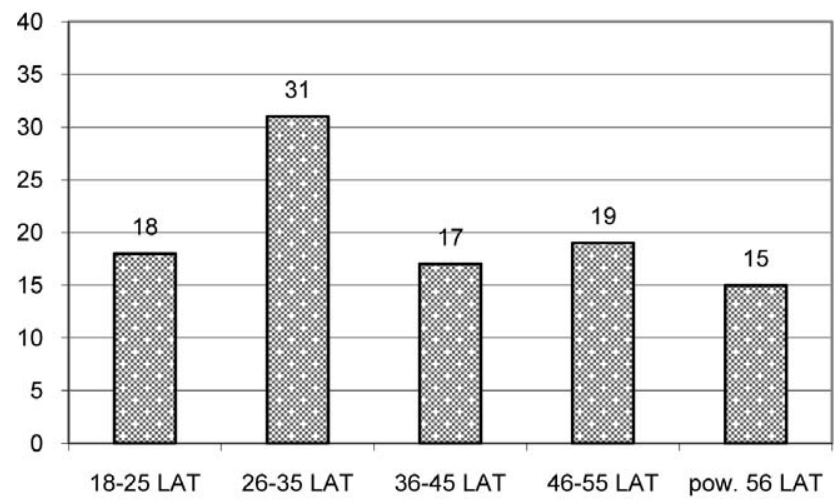

Źródło: opracowanie własne.

Jeżeli chodzi o poziom wykształcenia, najwięcej osób (41\%) posiada wykształcenie wyższe, a najmniej - podstawowe (12\%). Osoby wykształcone więcej podróżują, ponieważ mają stałą pracę i dochody. Młodzież podróżuje w celach poznawczych i kulturalno-rozrywkowych (ryc. 6).

Ryc. 6. Wykształcenie badanych osób

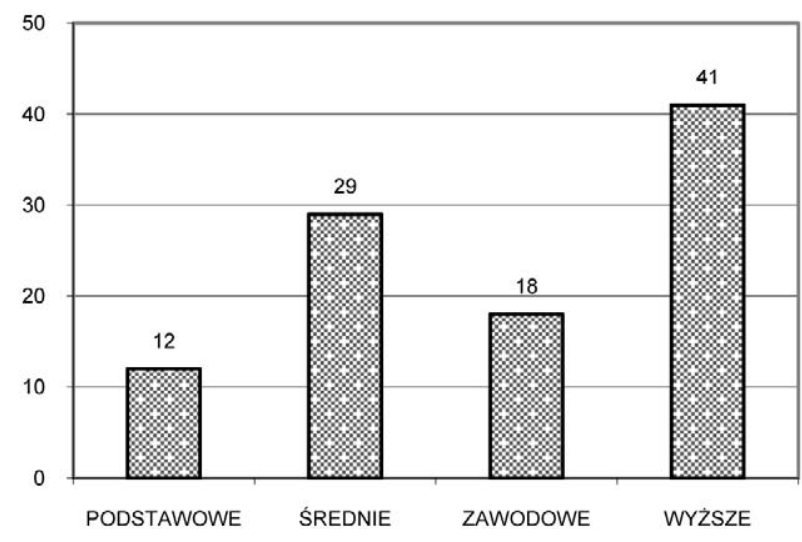

Źródło: opracowanie własne.

Najwięcej turystów przyjeżdża do „Bizolandii” z województwa świętokrzyskiego (23\%), najmniej z pomorskiego i zachodniopomorskiego (2\%). Tak niska frekwencja z województw północnej Polski związana jest zapewne z dużymi odległościami pomiędzy tymi województwami a obiektem, gdyż we wcześniejszej ankiecie zachodniopomorskie również zajmowało ostatnie miejsce. Największą liczbę turystów w 2005 roku stanowili mieszkańcy województw: świętokrzyskiego, małopolskiego i mazowieckiego, z których Zespół Pałacowy odwiedziło $40 \%$ ankietowanych. Oznacza to, że ten obiekt turystyczny stał się nie tylko popularny wśród okolicznych mieszkańców, ale także wśród mieszkańców innych województw (ryc. 7). 
Ryc. 7. Miejsce zamieszkania (województwo) osób przyjeżdżających do Zespołu Pałacowego w Kurozwękach

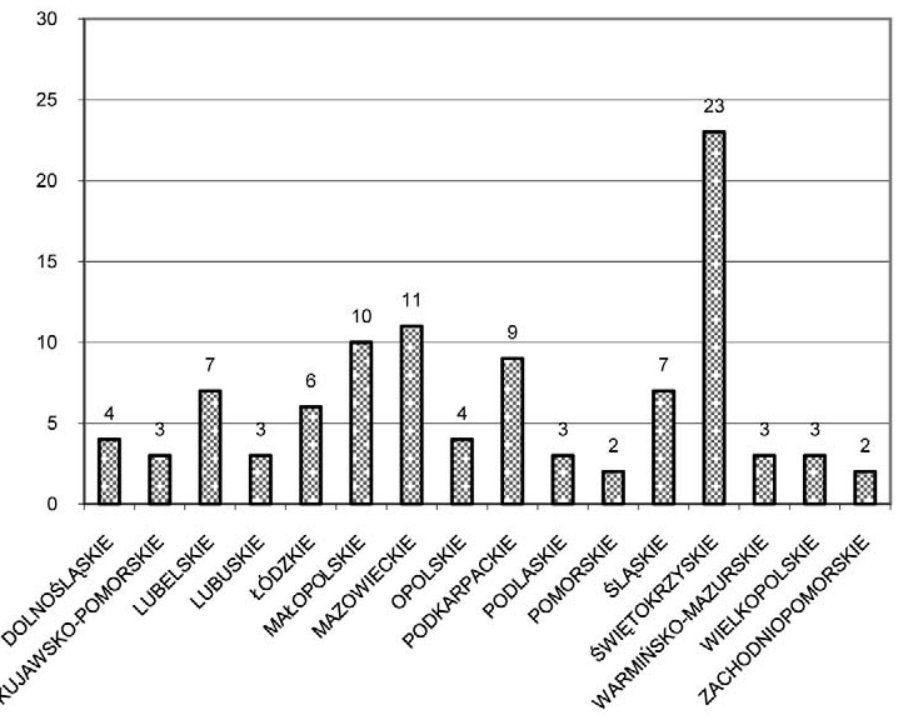

Źródło: opracowanie własne.

Następne pytanie zawarte w ankiecie dotyczyło możliwości uzyskania informacji na temat Zespołu Pałacowego. Na podstawie przeprowadzonych badań wynika, że najwięcej informacji respondenci uzyskują od znajomych i rodziny (41\%). Na drugim miejscu znalazł się internet (28\%), a nikt nie wskazał jako źródła informacji rozgłośni radiowych. Dla porównania również w 2005 roku najwięcej osób, aż 56\% ankietowanych, dowiedziało się o obiekcie od rodziny. Informacje o Zespole Pałacowym jako obiekcie zabytkowym, odbywających się imprezach kulturalnych oraz jako miejsca wypoczynku znajdują się w większości przewodników i, jak wykazały badania, blisko 15\% ankietowanych skorzystało z takiego źródła informacji (ryc. 8).

Ryc. 8. Źródło informacji ankietowanych na temat Zespołu Pałacowego

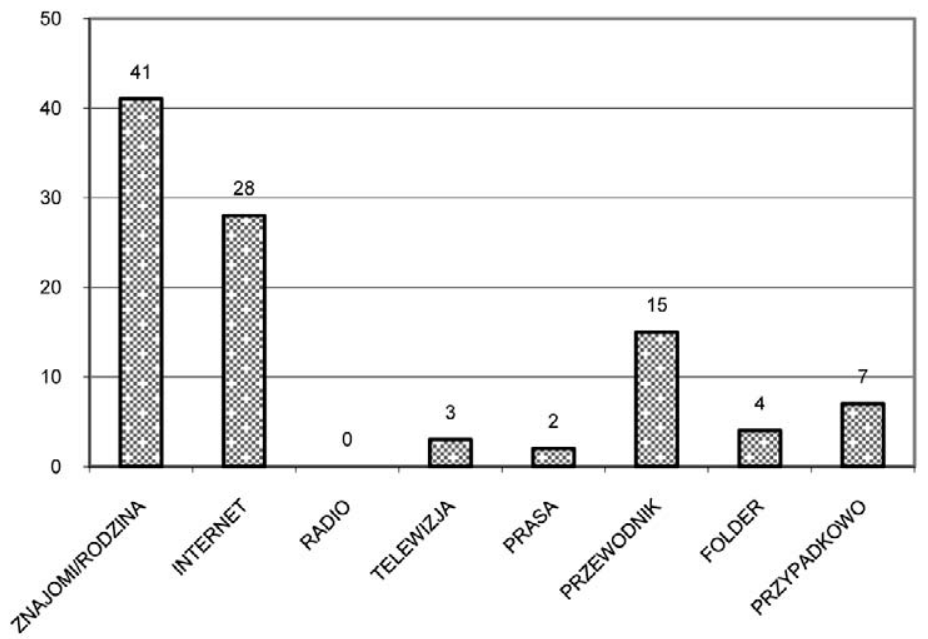

Źródło: opracowanie własne. 
Jedno z pytań dotyczyło możliwości dojazdu do Zespołu Pałacowo-Parkowego (ryc. 9). Nie zmienił się on w ciągu 4 lat, jednak badania wykazały, iż turyści są bardziej zadowoleni z jego oznakowania. Około 68\% ankietowanych uważa, że droga jest dobrze oznakowana, ale w nie najlepszym stanie.

Ryc. 9. Opinia dotycząca dojazdu do obiektu

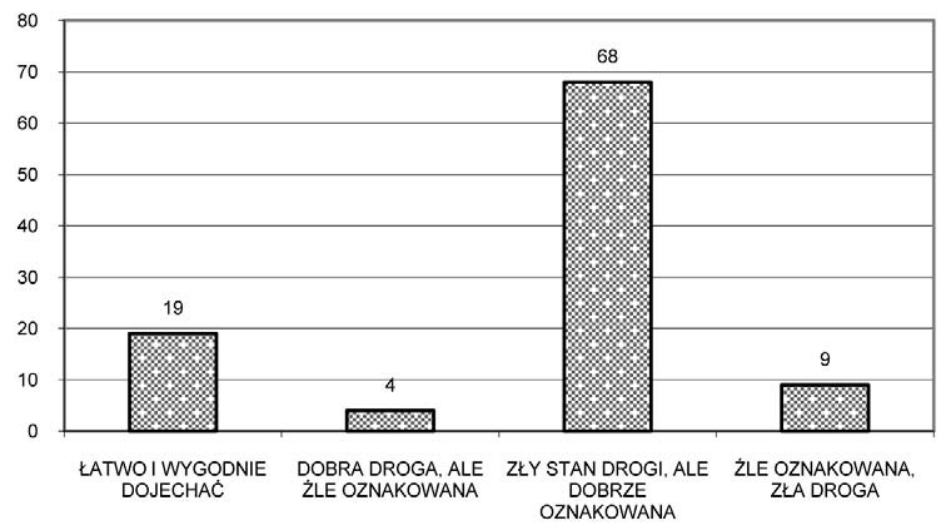

Źródło: opracowanie własne.

Kolejne pytania dotyczyły oceny obiektu hotelowego ze szczególnym uwzględnieniem udzielonego noclegu (ryc. 10). Prawie połowa ankietowanych (44\%) wystawiła ocenę dobra, chociaż na drugim miejscu ankietowani uznali standard zajmowanego przez nich pokoju jako przeciętny (36\%). Zależy to prawdopodobnie od wymagań poszczególnych turystów.

Ryc. 10. Ocena standardu pokoju przez ankietowanych

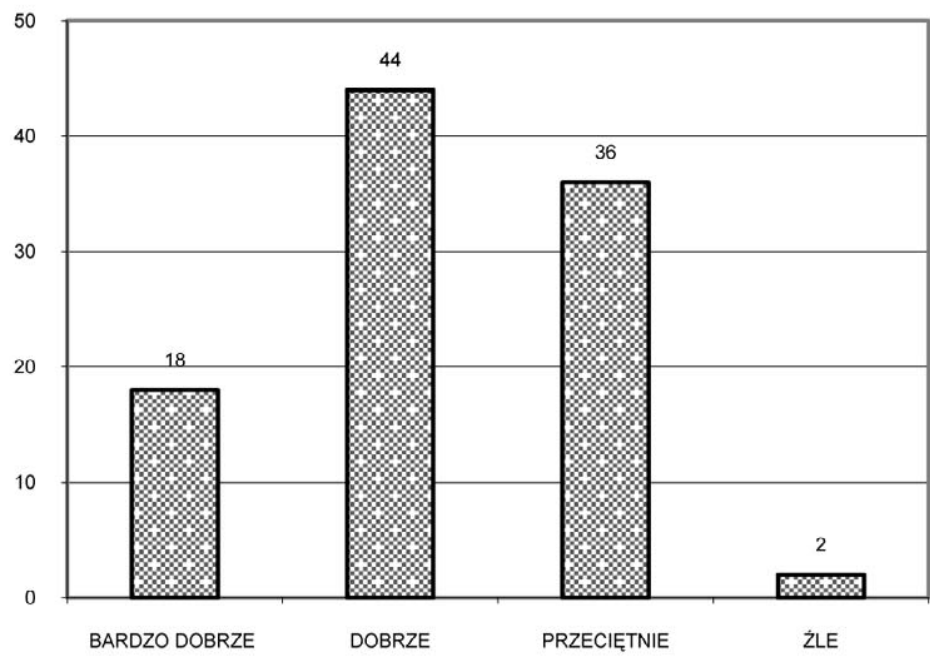

Źródło: opracowanie własne. 
Kolejnym zadaniem badanych było dokonanie oceny jakości usług wykonywanych w obiekcie. Najlepszą ocenę zdaniem respondentów uzyskało wyżywienie serwowane na terenie obiektu (ryc. 11). Ankietowani uznali wyżywienie w Zespole Pałacowym za bardzo dobre (54\%) bądź dobre (45\%).

Ryc. 11. Ocena bazy żywieniowej na terenie Zespołu Pałacowego

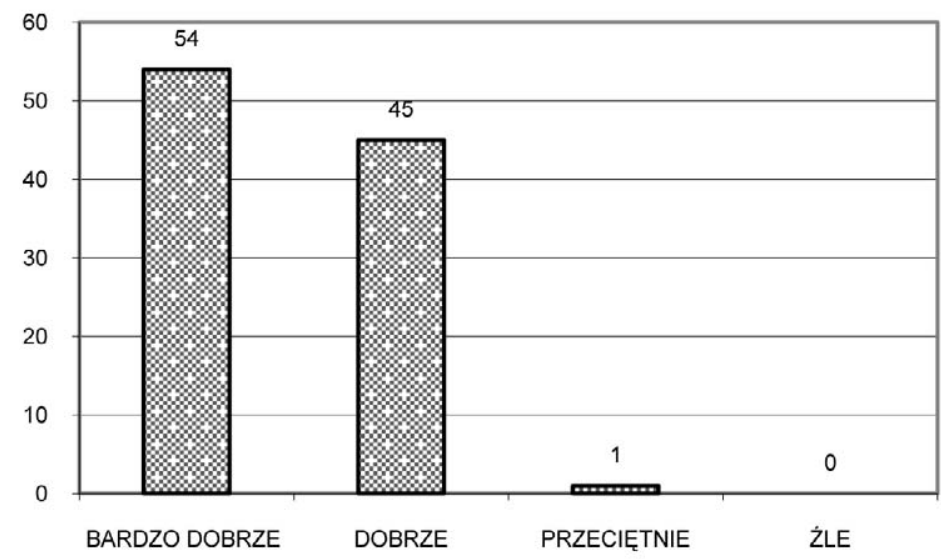

Źródło: opracowanie własne.

Rozrywka i rekreacja zadowoliła ankietowanych w stopniu dobrym i bardzo dobrym ( $47 \%$ i $24 \%$ wszystkich głosów). Część ankietowanych (26\%) uznała te dwie usługi za przeciętne (ryc. 12). Uzależnione jest to prawdopodobnie od wieku ankietowanych. Od zeszłego roku baza rozrywkowo-rekreacyjna na terenie obiektu się rozbudowuje, aby zaspokoić różne oczekiwania klientów. Ankietowani uznali, że czystość na terenie obiektu jest na poziomie dobrym (48\%), a $9 \%$ oceniło ją jako przeciętną.

Ryc. 12. Ocena dotycząca rozrywki i rekreacji

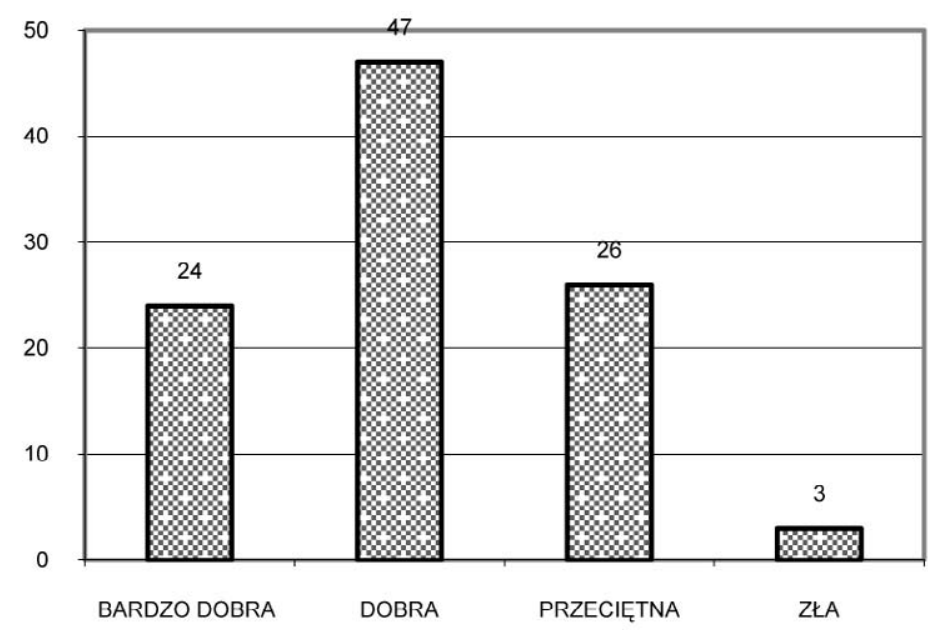

Żródło: opracowanie własne. 
Następnie badani turyści mieli dokonać oceny pracowników pod względem kompetencji i życzliwości. Troska o potrzeby klienta (ryc. 13), podobnie jak czystość oceniona została na dobrym poziomie (49\%). Część ankietowanych uznała ją za przeciętną (38\%).

Ryc. 13. Ocena dotycząca troski o potrzeby klienta

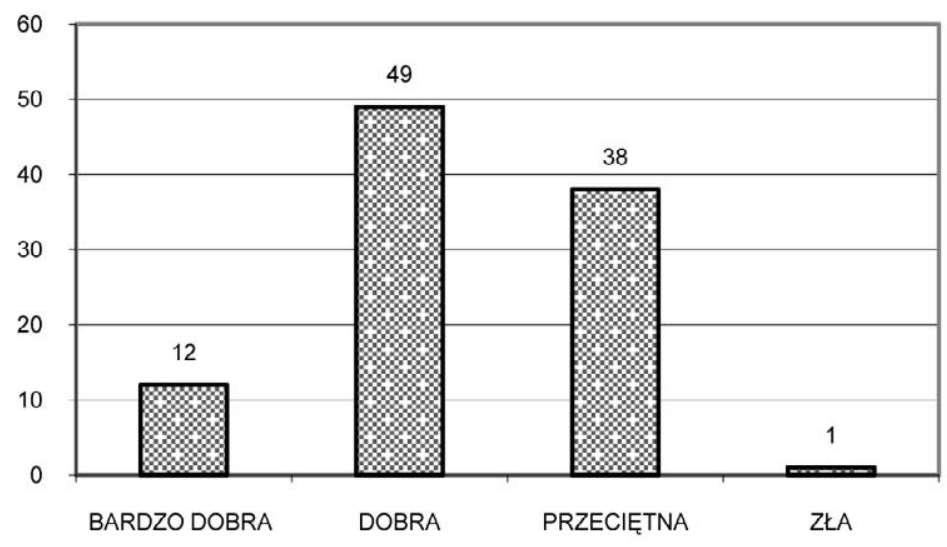

Źródło: opracowanie własne.

Respondentów poproszono również o ocenę lokalizacji Zespołu Pałacowego (ryc. 14). Większość ankietowanych uznało ją za bardzo dobrą (57\%).

Ryc. 14. Ocena dotycząca lokalizacji obiektu

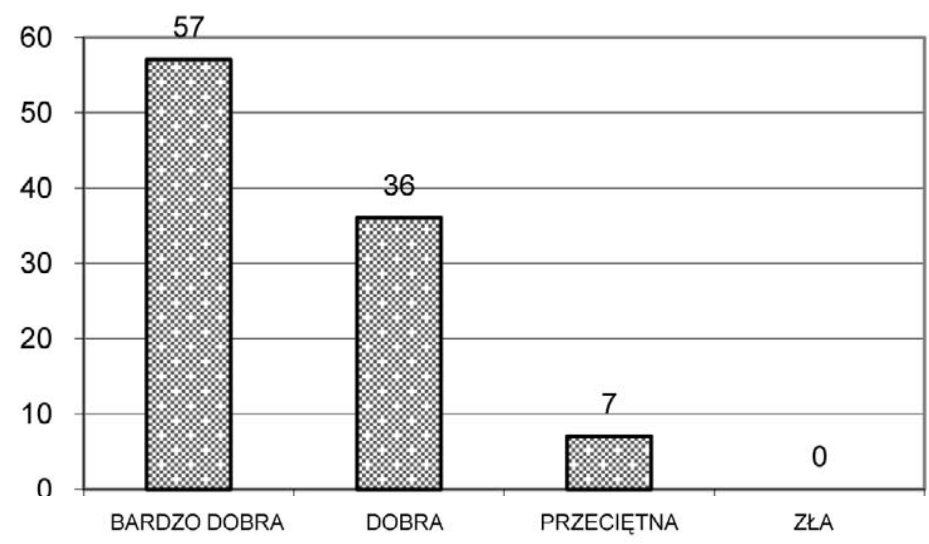

Źródło: opracowanie własne.

Bezpieczeństwo na terenie obiektu również zadowoliło ankietowanych w stopniu bardzo dobrym (ryc. 15). Uznało tak blisko 55\% ankietowanych. 
Ryc. 15. Ocena dotycząca bezpieczeństwa

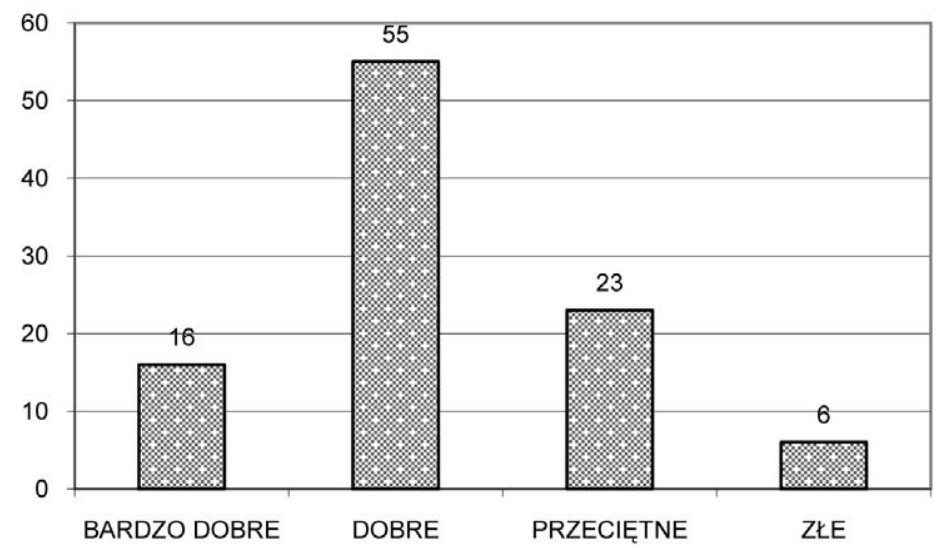

Źródło: opracowanie własne.

Zespół Pałacowy leży w naturalnie pięknym miejscu, zapewne dlatego ankietowanym podobało się jego otoczenie i zagospodarowanie. $49 \%$ ankietowanych przyznało mu ocenę dobrą (ryc. 16).

Ryc. 16. Ocena obiektu oraz jego zagospodarowania

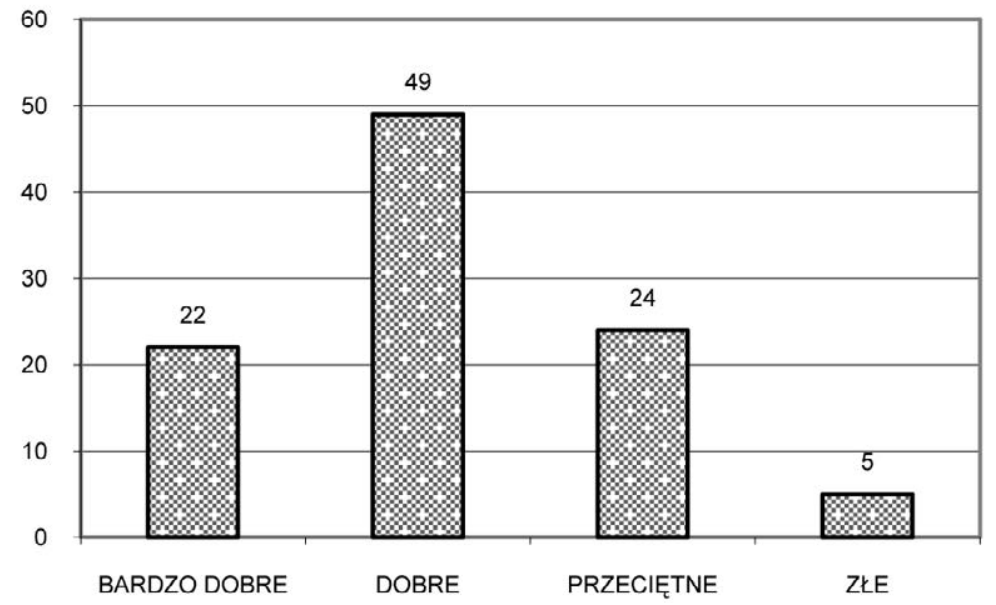

Źródło: opracowanie własne.

Respondentów poproszono również o ocenę pracowników. Blisko 47\% ankietowanych stwierdziło, że są kompetentni, ale nie zawsze życzliwi. Kierownictwo musi zwrócić na to szczególną uwagę, ponieważ wiadomo, iż czasem wraca się do danego obiektu właśnie ze względu na miłą i życzliwą obsługę (ryc. 17). 
Ryc. 17. Ocena pracowników obiektu

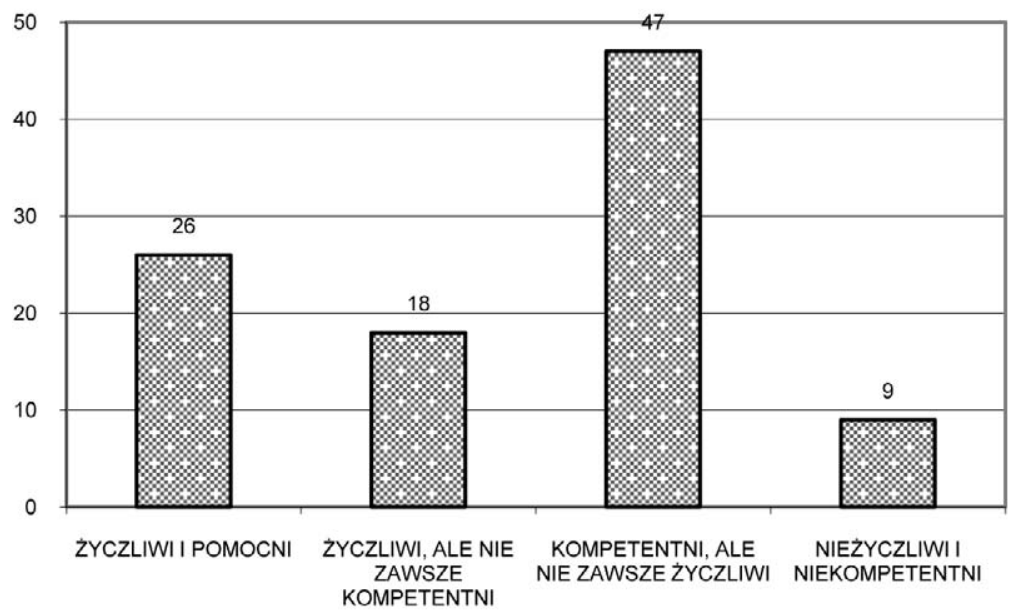

Źródło: opracowanie własne.

Badani mieli również podać cel przyjazdu, czas pobytu oraz o określić, jak często korzystają z usług Zespołu Pałacowego. Turyści przyjeżdżali do „Bizolandii” głównie po to, aby wypocząć (69\%). Kilkoro ankietowanych (4\%) przyjechało tam w innym celu, np. udziału w balu sylwestrowym. Niektórzy badani mogli kwalifikować takie imprezy, jak bale czy wesela, do wypoczynku (ryc. 18).

Ryc. 18. Cel przyjazdu ankietowanych

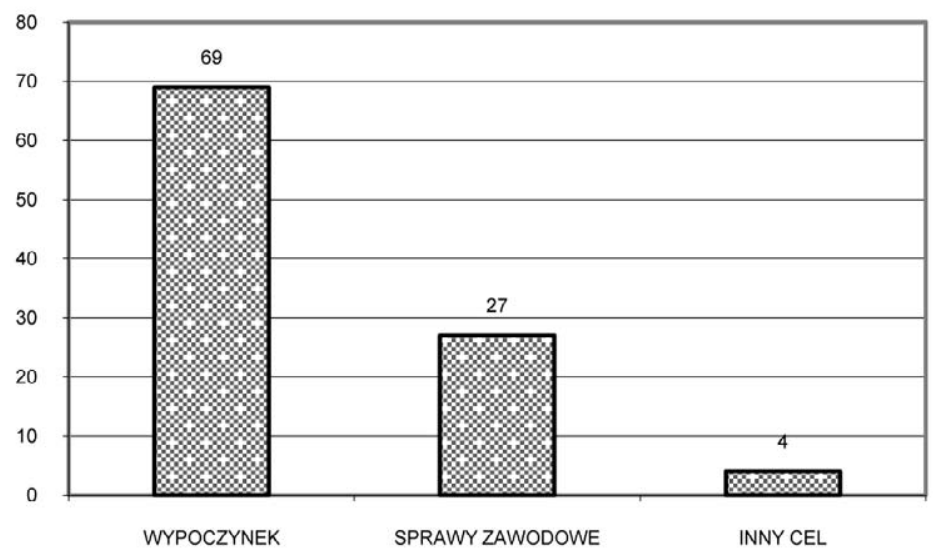

Źródło: opracowanie własne.

Generalnie ankietowani przyjeżdżali do obiektu na jedną dobę (52\%), bądź 2-3 dni (40\%). Rzadko zostawali w obiekcie dłużej niż 7 dni (4\%) (ryc. 19). 
Ryc. 19. Długość pobytu ankietowanych

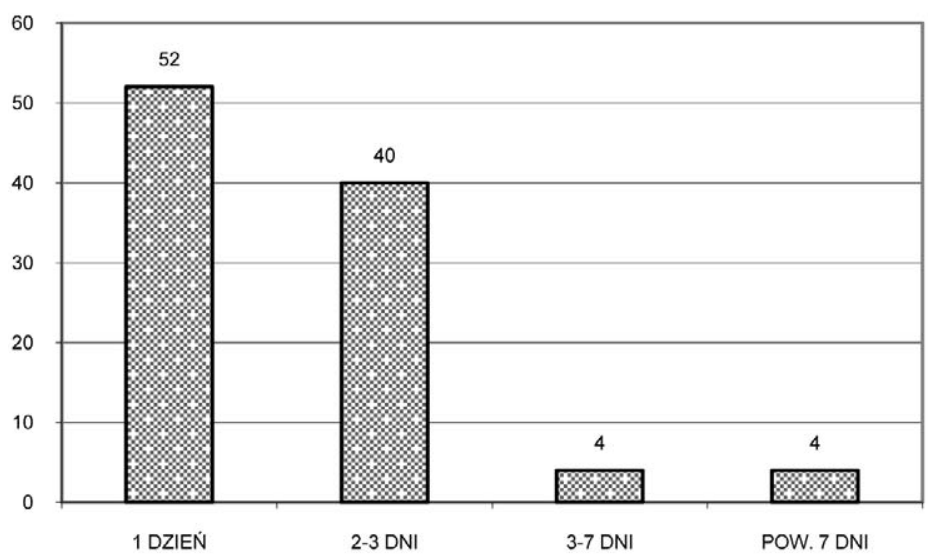

Źródło: opracowanie własne.

Mimo że obiekt czynny jest już od prawie 10 lat, około $41 \%$ ankietowanych było w nim po raz pierwszy, $42 \%$ odwiedziło go już drugi lub trzeci raz, a tylko $17 \%$ turystów jest tam częstym gościem (ryc. 20).

Ryc. 20. Częstotliwość korzystania z usług obiektu przez ankietowanych

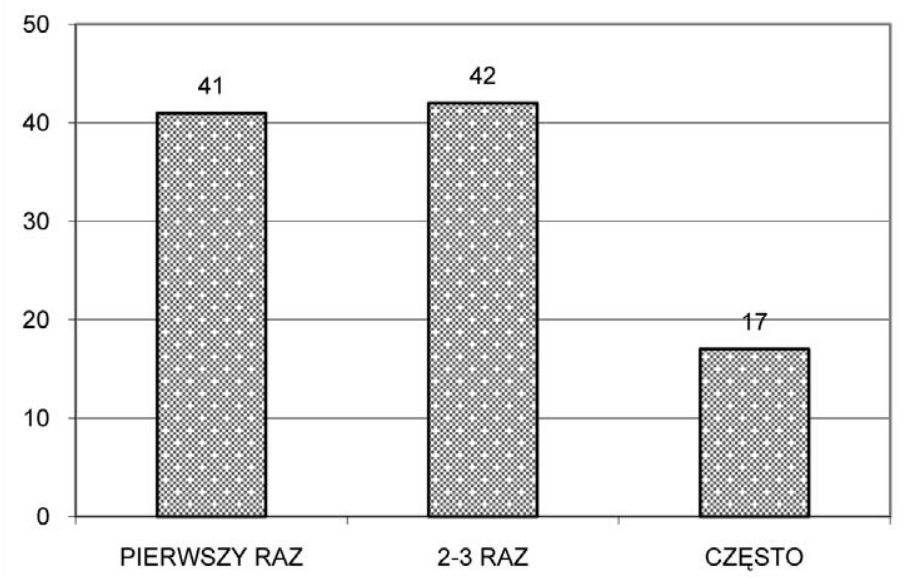

Źródło: opracowanie własne.

Jeżeli chodzi o chęć powtórnego przyjazdu do „Bizolandii”, to aż $61 \%$ ankietowanych stwierdziło, że chętnie przyjedzie tam powtórnie. 
W kolejnym pytaniu ankiety należało ocenić usługi realizowane w tym obiekcie w skali 1-10 (ryc. 21) oraz podać własne uwagi lub spostrzeżenia na temat jakości wykonywanych usług. W skali dziesięciostopniowej blisko 30\% ankietowanych wystawiło obiektowi za całokształt ocenę 7 .

Ryc. 21. Ocena usług realizowanych w tym obiekcie w skali 1-10 (1 - najniżej, 10 - najwyżej)

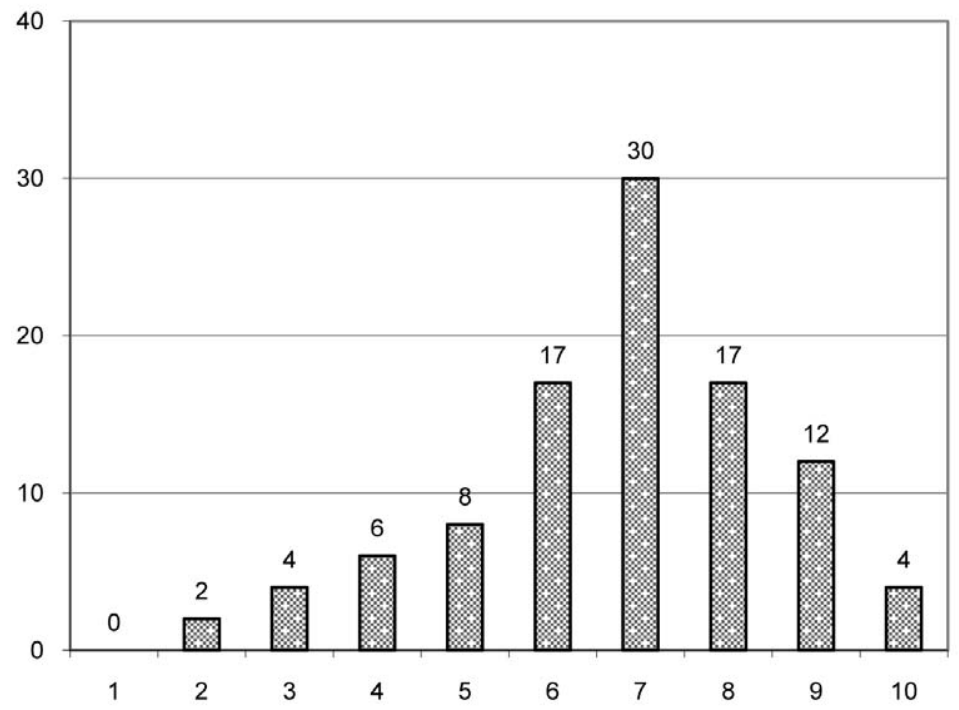

Źródło: opracowanie własne.

Podsumowując przeprowadzone badania sondażowe, należy stwierdzić, że Zespół Pałacowy jest nadal atrakcyjny turystycznie i turyści chętnie tam przyjeżdżają. Należy tylko zadbać o to, aby turyści dobrze wypoczywali i spędzali wolny czas, zapewniając im nowe atrakcje. Bardzo istotne w opinii respondentów jest zwrócenie większej uwagi na estetykę obiektu i lepszą obsługę turystów. Badania ankietowe umożliwiły również turystom ocenę i podanie własnych spostrzeżeń oraz uwag dotyczących jakości usług. Badani narzekali głównie na drogę „,strasznie się kurzy” albo „straszne błoto” (turyści z województwa małopolskiego i mazowieckiego). Było również kilka uwag dotyczących niewłaściwego zachowania obsługi i chaosu wśród pracowników, co może wynikać z braku kompetencji niektórych pracowników. Poza tymi uwagami turyści byli raczej zadowoleni z usług.

\section{Ocena strategii rozwoju Zespołu Palacowego}

Zespół Pałacowy w Kurozwękach nie ma jasno wytyczonej strategii. Jednak na podstawie przeprowadzonych badań, wywiadów i analiz można podjąć się sprecyzowania takiej strategii. Dobrze opracowana strategia powinna wytyczać drogę, którą firma chce podążać i stale ją doskonalić. Powinna odpowiedzieć na pytanie o konkretne możliwości działania, przewidywane zmiany, środki potrzebne do realizacji zadań i ich alokację oraz pozycję firmy w przyszłości. Innymi słowy: powinna być odpowiedzią na przyszłe szanse. Na stworzenie takiej strategii składają się cztery zasadnicze elementy:

- domena działania,

- strategiczna przewaga, 
- cele do osiagnięcia,

- funkcjonalne programy działania (Obłój 1993).

Domena działania określa, gdzie i komu przedsiębiorstwo zamierza sprzedawać swoje wyroby lub usługi. Zespół Pałacowy jest otwarty na:

- klientów indywidualnych,

- wycieczki zorganizowane,

- klientów urlopowych,

- imprezy rodzinne,

- imprezy biznesowe,

- imprezy masowe.

W przyszłości kierownictwo firmy chce zawęzić grono klientów.

Strategiczna przewaga polega na tym, aby w ramach wybranej branży być atrakcyjniejszym partnerem niż inne firmy. Zespół Pałacowy uzyskał tę przewagę, wprowadzając na rynek produkt, którego nie było nigdzie w Polsce, a mianowicie rozpoczynając hodowlę bizonów amerykańskich. Zwierzęta te przyciągają do Kurozwęk większość turystów. Przewaga ta jest cały czas umacniana za sprawą kolejnej unikatowej atrakcji, mianowicie labiryntu w kukurydzy. Co roku jest on tworzony według innego schematu.

Cele strategiczne są ważnym uzupełnieniem wyboru działania i strategicznej przewagi nad konkurentami. Określają, co konkretnie firma chce osiagnąć w kolejnych okresach. Z punktu widzenia rozciągłości w czasie cele mogą być długo-, średnio- czy też krótkoterminowe. Takich celów Zespół Pałacowy ma bardzo dużo. Jedne są realizowane, inne odkładane w czasie w zależności od danych potrzeb rynku. Cele te określa głównie właściciel przedsiębiorstwa. Do najważniejszych celów należą:

1. Zniesienie sezonowości będącej głównym problemem przedsiębiorstwa. Największe zainteresowanie obiektem przypada na okres od maja do października, później zaczyna się martwy sezon. Właściciel poprzez dokładanie różnych atrakcji w sezonie jesienno-zimowym dąży do tego, aby obiekt ten był atrakcyjny turystycznie przez cały rok i przez cały rok przynosił dochody (zyski osiągane w sezonie letnim nie mają pokrywać strat w sezonie zimowym).

2. Rozwój ekologiczny. Ekologia jest wymogiem, który w ostatnich latach stał się wręcz modny. Właściciel chce wykorzystać tę sytuację, aby przyciągnąć nowych klientów. W tym celu zawierają się inne, mniejsze cele:

- budowa małej hydroelektrowni, która ma stać się źródłem zasilania dla Zespołu Pałacowo-Parkowego,

- odbudowa stawów rybnych na potrzeby rekreacji,

- kontynuowanie unikalnego labiryntu w kukurydzy,

- budowa oczyszczalni ścieków na potrzeby pałacu,

- zakup nowych zwierząt do pokazów.

3. Stworzenie nowych atrakcji w celu zaspokojenia zmieniających się potrzeb klientów, m.in. udostępnienie lochów w pałacu, muzeum rodu Popielów, wybudowanie parku sztuk pięknych, przystosowanie rzeki Czarnej do spływu kajakowego i poszerzenie jej w celu utworzenia małej plaży, organizowanie imprez kulturalnych oraz do trzech imprez masowych rocznie.

4. Rozwój bazy hotelowej do co najmniej 40 pokoi.

5. Zakończenie prac remontowych.

6. Zakup nowoczesnego sprzętu w celu optymalizacji zysku przy minimalizacji nakładów. 
Funkcjonalne programy działania są przełożeniem strategii na konkretne działania na każdym stanowisku pracy, na codzienne zachowania każdego pracownika. Skuteczne programy działania mają trzy aspekty:

- określają co, kto i kiedy będzie robił oraz w jaki sposób wiąże się to z globalną strategią firmy (łączą one bieżące zarządzanie ze strategiczną przyszłością),

- zakładają stałą konieczność poprawy i usprawniania,

- obejmuja funkcjonowanie całej firmy (dla każdego obszaru funkcjonowania firmy trzeba przygotować programy działania ze ściśle określonym okresem realizacji).

W badanej firmie nie ma konkretnych programów dla poszczególnych stanowisk. Programy te powstają spontanicznie w zależności od aktualnych potrzeb.

\section{Słabe i mocne strony rozwoju firmy - analiza SWOT}

W analizie strategicznej szczególne znaczenie ma metoda SWOT, służąca do badania otoczenia organizacji oraz analizy jej wnętrza. Analiza SWOT jest opisywana w literaturze jako jedna z metod rejestracji i klasyfikacji czynników warunkujących strategię firmy (Gierszewska, Romanowska 1995). Jest oparta na prostym schemacie klasyfikacji (ryc. 21) i polega na zidentyfikowaniu czterech grup czynników, opisaniu ich wpływu na rozwój organizacji, a także możliwości osłabiania lub wzmacniania siły ich oddziaływania. Zderzenie ze sobą szans i zagrożeń z mocnymi i słabymi stronami firmy pozwala na określenie jej pozycji strategicznej, a także może być źródłem interesujących pomysłów strategii.

Ryc. 22. Klasyfikacja czynników wpływających na pozycję strategiczną organizacji w analizie SWOT

Czynniki pozytywne

Czynniki negatywne

\begin{tabular}{l|l|l|}
\cline { 2 - 3 } $\begin{array}{l}\text { Czynniki } \\
\text { zewnętrzne }\end{array}$ & Szanse & Zagrożenia \\
\cline { 2 - 3 } $\begin{array}{l}\text { Czynniki } \\
\text { wewnętrzne }\end{array}$ & Mocne strony & Słabe strony \\
\cline { 2 - 3 } & &
\end{tabular}

Źródło: opracowanie własne.

Zasadnicza część diagnostyczna analizy SWOT polega na określeniu słabych i silnych stron firmy oraz zewnętrznych szans i zagrożeń. Silnymi stronami firmy są przede wszystkim jej unikalne zasoby, umiejętności lub inne aspekty odróżniające ją w pozytywny sposób od konkurencji. Silna strona firmy to specyficzna przewaga, na której można budować strategię np. lokalizacja, dostęp do tanich źródeł finansowania, patenty, własna technologia, lojalni pracownicy. Słabymi stronami firmy są wszystkie te aspekty jej funkcjonowania, które ograniczają sprawność firmy lub blokują jej rozwój, np. zadłużenie, przestarzały park maszyn, słaby marketing. W ramach analizy zewnętrznej należy rozważyć i ocenić takie dziedziny, jak: konkurencja, postęp techniczny (technologie), sytuacja w gospodarce krajowej i światowej, w tym kryzys, inflacja, działalność rządu, prawo, podatki oraz regulacje celne. Wyniki przeprowadzonej analizy SWOT w firmie przedstawia tabela 1.

W analizie SWOT wyróżniamy trzy etapy:

- identyfikację i analizę szans i zagrożeń,

- identyfikację i analizę mocnych oraz słabych stron przedsiębiorstwa,

- określenie pozycji strategicznej przedsiębiorstwa i kierunków jego rozwoju. 
Tab. 1. Wyniki analizy SWOT w Zespole Pałacowym w Kurozwękach

\begin{tabular}{|c|c|}
\hline $\begin{array}{l}\text { SZANSE } \\
\text { - umiarkowana rywalizacja w sektorze } \\
\text { - otwarcie się rynków zagranicznych na polskie } \\
\text { towary i usługi } \\
\text { - dopływ zachodniej technologii i kapitału } \\
\text { - rozszerzenie linii produktów w związku } \\
\text { z większymi oczekiwaniami klientów } \\
\text { - możliwość poszerzania asortymentu } \\
\text { - rosnące zapotrzebowanie na usługi turystyczne } \\
\text { - nacisk Unii i Polski na rozwój obszarów } \\
\text { wiejskich } \\
\text { - wykorzystanie funduszy unijnych } \\
\text { - bogacenie się społeczeństw }\end{array}$ & $\begin{array}{l}\text { ZAGROŻENIA } \\
\text { • możliwość pojawienia się nowych } \\
\text { - konkurentów } \\
\text { - kosztowne wymagania i regulacje prawne } \\
\text { - kryzys gospodarczy kraju } \\
\text { - wahania waluty } \\
\text { - wzrożenie kredytów } \\
\text { - utrzymujące się wysokie koszty pracy } \\
\text { i kapitału }\end{array}$ \\
\hline $\begin{array}{l}\text { MOCNE STRONY } \\
\text { - szeroka linia produktów i usług } \\
\text { - dobre powiązania z dostawcami i odbiorcami } \\
\text { • kooperacja z firmami zagranicznymi } \\
\text { - innowacyjny produkt } \\
\text { - malowniczy i urozmaicony krajobraz } \\
\text { - duży stopień lesistości okolicy } \\
\text { - korzystne warunki do rozwoju rolnictwa } \\
\text { ekologicznego } \\
\text { - duży potencjał do rozwoju ruchu turystycz- } \\
\text { nego } \\
\text { - znakomite warunki do rozwijania różnorod- } \\
\text { nych form turystyki specjalistycznej } \\
\text { - znakomite warunki do rozwijania edukacji } \\
\text { ekologicznej i turystyki edukacyjnej }\end{array}$ & $\begin{array}{l}\text { SŁABE STRONY } \\
\text { - brak jasno wytyczonej strategii } \\
\text { - brak badań rynku i skutecznego marketingu } \\
\text { - jakość usług na przeciętnym poziomie } \\
\text { - brak liderów wśród kadry kierowniczej } \\
\text { - słaby wizerunek firmy } \\
\text { - zły stan techniczny drogi dojazdowej i dróg po } \\
\text { obiekcie } \\
\text { - słabo rozwinięta baza rekreacyjna } \\
\text { - niewystarczająca baza noclegowa } \\
\text { - brak atrakcyjnych programów pobytu poza } \\
\text { głównym sezonem turystycznym }\end{array}$ \\
\hline
\end{tabular}

Źródło: opracowanie własne.

Analizując szanse i zagrożenia w Zespole Pałacowym w Kurozwękach, należy zauważyć, że głównym zagrożeniem jest sytuacja gospodarcza w kraju, na którą przedsiębiorstwo nie ma wpływu. Firma powinna zatem wykorzystać swoje szanse, przede wszystkim dostosować się do potrzeb klienta i poszerzać swój asortyment. Należy również zwracać uwagę na nową konkurencję, która może zagrozić sytuacji firmy, i kontrolować ją. Analizując czynniki wewnętrzne, powinno się opierać na mocnych stronach i wzmacniać strony słabe. Należy zacząć od jasno wytyczonej strategii i skutecznego marketingu. Są to najważniejsze aspekty prawidłowego działania firmy. Trzeba również podnieść jakość usług za sprawą wykwalifikowanej kadry oraz zainwestować w reklamę i wizerunek firmy. Atutami tego przedsiębiorstwa są: bogate doświadczenie zagraniczne właściciela, wdrażanie zagranicznych technologii oraz współpraca z firmami spoza naszego kraju. Plusem jest także położenie Zespołu Pałacowego na ekologicznych terenach, w pobliżu zbiorników wodnych i kompleksów leśnych oraz w niedalekiej odległości od dużego miasta. 


\section{Proponowana strategia rozwoju firmy}

Preferowana czy przyjęta przez społeczność przedsiębiorstwa opcja strategiczna powinna stać się dla specjalistów od planowania podstawą do opracowania strategii. Jest ona projektem przedstawiającym cele i zadania długookresowe oraz zamierzenia prowadzące do osiagnięcia założonych celów, a więc zawierających pakiet środków zapewniających ich osiagnięcie w sposób umożliwiający redukcję ryzyka i zwiększenie szans powodzenia.

Obszar Zespołu Pałacowego jest bogaty w walory przyrodnicze, dobra kultury i inne wytwory działalności człowieka, które stanowią trzon i warunkują program zagospodarowania turystycznego obiektu. Właściwe zagospodarowanie turystyczne i rozwój zgodny z przesłankami ekologicznymi utworzy unikatowy wizerunek firmy. Celem proponowanej strategii jest przedstawienie potencjału turystycznego oraz osiąnnięcie atrakcyjnego i nowoczesnego produktu turystycznego promującego przedsiębiorstwo w skali krajowej i międzynarodowej.

Głównym założeniem strategicznym proponowanej strategii jest rozwój turystyki na terenie Zespołu Pałacowego w celu osiagania i zwiększania dochodów poprzez wzrost liczby przyjazdów i wydłużenie czasu pobytu turystów.

Główne cele i kierunki strategii rozwoju:

1. podniesienie jakości oferowanych usług poprzez zatrudnienie wykwalifikowanej kadry bądź organizowanie systematycznych szkoleń,

2. opracowanie zintegrowanego i skutecznego systemu promocji i marketingu,

3. przydział zadań na poszczególne stanowiska pracy (każdy dział ma mieć osobną kadrę kierowniczą),

4. kontrola czasu i obowiązków pracowników (przemęczanie się prowadzi do złego wykonywania pracy),

5. zainwestowanie w architekturę krajobrazu,

6. poprawa stanu dróg dojazdowych oraz wyznaczenie dogodnej drogi zwiedzania,

7. zamieszczenie tablicy informacyjnej dotyczącej zagospodarowania obiektu,

8. rozwój rekreacji na terenie obiektu,

9. poszerzenie bazy noclegowej z uwzględnieniem wycieczek szkolnych,

10. wydłużenie sezonu turystycznego poprzez przygotowania turystycznych ofert na cały rok.

Obiekt, aby był atrakcyjny turystycznie, musi być również odpowiednio promowany. Promocja przedsiębiorstwa powinna być bezpośrednio skierowana do rynku konsumenta, czyli przede wszystkim do ludności polskiej mieszkającej w dużych aglomeracjach przemysłowych. Działania promocyjne powinny być prowadzone w różnorodnych formach, w zależności od możliwości finansowych, np. poprzez:

- media - reklamę, relacje z wydarzeń,

- kontakty z grupami opiniotwórczymi,

- materiały promocyjne - wydawnictwa, filmy, CD,

- kampanie promocyjne - targi i wystawy,

- warsztaty, seminaria, szkolenia,

- informację turystyczną - INFOTUR,

- internet.

Bez odpowiednio prowadzonych i skutecznych działań promocyjnych skierowanych do właściwego rynku turystycznego nie można zakładać rozwoju turystyki. Promocja rzutuje na decyzje turysty o wyborze odpowiedniego dla niego miejsca wypoczynku. Kolejne odwiedziny danego terenu przez turystę wynikają ze stopnia jego zadowolenia z pierwszego pobytu. Celem promocji powinno być zatem zachęcanie turystów do odwiedzin danego obiektu poprzez wyrobienie u nich opinii o szerokiej ofercie i wielu możliwościach spędzania wolnego czasu. 
Należy również zadbać o odpowiedni wizerunek firmy. Turyści z pewnością wybiorą ten obszar, o którym więcej wiedzą, szczególnie o możliwościach i bogactwie ofert, umożliwiających interesujące spędzanie wolnego czasu. Poprzez stworzenie wyrazistego wizerunku firmy, odróżniającego ją od konkurencji, w efekcie kształtuje się oryginalną przestrzeń turystyczną.

Realizacja strategii wymaga konsekwencji, współpracy wielu podmiotów oraz nieustannej koordynacji ich działań. Realizacja strategii musi być stale monitorowana, a zapisy strategiczne dostosowane do zmieniających się uwarunkowań społeczno-gospodarczych.

\section{Literatura}

1. Gierszewska G., Romanowska M., 1995, Analiza strategiczna przedsiębiorstwa, PWE, Warszawa.

2. Obłój K., 1993, Strategia sukcesu firmy, PWE, Warszawa.

3. Penc J., 1997, Strategie zarzqdzania, Agencja Wydawnicza Placet, Warszawa.

4. Stabryła A., 2002, Zarzqdzanie strategiczne w teorii i praktyce, Wydawnictwo Naukowe PWN, Warszawa-Kraków.

\section{The Strategy of the Development and Quality Estimation Dealing with Services Based on the Example of a $14^{\text {th }}$-century Palace in Kurozwęki in the Light of the Survey Investigations}

The strategy in the development and the process of creating the quality of services is one of the most important elements the business management.

A $14^{\text {th }}$-century Palace in Kurozwęki is one of the most expansive and developing enterprises in the Świętokrzyski region, which has been becoming the crucial touristic centre for this province. In the present article, due to the basic conditioning, directions of the touristic enterprise development of the Palace in Kurozwęki were shown. They concerned the period of two years from 2006 up to 2008. In order to estimate the activities and the quality of services in the Palace in Kurozwęki, the survey investigations were conducted by the use of questionnaires. The $14^{\text {th }}$-century Palace in Kurozwęki has no straightforward strategies indicated. However, on the basis of the conducted investigations, interviews and analyses, it was decided to specify such strategy. The strategy presented by the author should indicate aims, which this firm must realize and constantly develop. This strategy enables the firm to deal with the specific activities, transformations as well as to gain the required funds in order to realize tasks and their allocation together with the stabilization of the firm place on the market in the future. Any enterprise has to consider the future, not only in the aspect of the existence, but also in the light of the development. The strategic benefits do not depend on the product or service prices, moreover, on their increase but they relay on the high quality of the production, the process of getting ahead others in the study of modern goods as well as on the improvement and/or introduction of new technologies and organizations. 